\title{
Characterizing Land Use Systems within Awoja Watershed
}

\author{
Charles Aben ${ }^{1}$, John James Okiror ${ }^{1}$, Jacob Godfrey Agea ${ }^{1} \&$ Esbern Friis Hansen ${ }^{2}$ \\ ${ }^{1}$ Department of Extension and Innovation Studies, College of Agricultural and Environmental Sciences, \\ Makerere University, Kampala, Uganda \\ ${ }^{2}$ Danish Institute for International Studies, Copenhagen, Denmark
}

Received: April 15, 2019 Accepted: June 20, 2019 Online Published: July 5, 2019

doi:10.22158/ees.v2n2p1 URL: http://dx.doi.org/10.22158/ees.v2n2p1

\section{Abstract}

This manuscript analyses trends in land use changes in Awoja Watershed with the aim of exploring the underlying causes of degradation in this watershed within the context of frequent draughts and floods. Changing trends of land use characteristics were used as indicators of ineffectiveness of control of access to resource use in the watershed. The study was carried out in the districts of Katakwi, Amuria and Sorotiin Eastern Uganda where the watershed is experiencing increasing trends of degradation despite the presence of elaborate watershed management institutions. The study used Remote Sensing, and focus group discussions to acquire relevant data on land use changes and their perceived causes. Perceptions of respondents on the effectiveness of the local governance processes were generated. The findings show increase in built-up areas from 0.21\% between 1986-1996; to 3.28 between 2006 and 2016 and a notable decrease in forest cover from $107.48 \mathrm{Km}^{2}$ in 1,986 to $6.94 \mathrm{Km}^{2}$ by 2016. The results also show a dramatic increase in small scale farming area from $629.44 \mathrm{Km}^{2}$ to $2,376.64 \mathrm{Km}^{2}$ from 1986-2016 while the area of wetland reduced from 2,810.47 $\mathrm{Km}^{2}$ to $1,355 \mathrm{Km}^{2}$ over the same period. Results from focus group discussions revealed that although climatic and demographic factors were responsible for land use changes in Awoja, control of access to natural resources was inadequate to stop degradation. Climatic factors mentioned included increased frequency of floods and draughts that were perceived to have been responsible for changes in vegetation cover, water levels and infrastructure. Socio economic factors driving the changes in land use included increased cultivation of wetlands and communal land, increased sale of fuel wood, charcoal and sand, increased migration of cattle herders into the watershed during draughts and out of it during floods and increased fishing. While climatic factors were important, socio political factors such as displacements of communities, resettlements in the fragile environment brought about by government efforts to demarcate wetlands and wild life conservation areas were cited as drivers of degradation. The study concludes that besides climatic factors, inadequate management of access to resources was contributing to degradation of the watershed. 


\section{Keywords}

watershed management, land use changes, climate change

\section{Introduction}

Land use/cover changes have now emerged as a global phenomenon and perhaps the most significant regional anthropogenic disturbance to the environment (Egeru \& Majaliwa, 2009). The rate of land use/cover change is high and is escalating globally (Krumhanslet al., 2015; Palmer, 2009; Townsend et al., 2011). Africa is said to have the fastest rate of deforestation in the world as a result of overdependence on primary resources (Ademiluyi et al., 2008).

Although the cause for most land use/cover changes is deemed to be population growth (Ramankutty et al., 2002b) there are several other interacting factors involved. In Egypt, Ibrahim and Mosben(2015) showed a decline of agricultural land while in India, land use cover change of $88.8 \%$ was due to increase in built up area. In essence both land use/cover changes are products of prevailing interacting natural and anthropogenic processes. Land use/cover change detection allows for the identification of major processes of change (Fasona \& Omojola, 2005).

Traditionally, local institutions have been instrumental in safeguarding resources, including the protection of forests and watersheds (Agrawal, 2010). In Uganda today, the role of Institutions has been enhanced by decentralization of natural resource management. This has empowered district land offices, fisheries offices, Agriculture of Forestry officials with facilities and resource protection enforcement tools (MLG Report, 2017). In the face of climate change therefore, Institutions are profoundly influencing implementation of adaptation to climate change, an idea also supported by Agrawal et al. (2009) when he notes that institutions have been instrumental in facilitating adaptation and channeling external resources. It should be noted however that where climate change adaptation measures have given less attention to social and institutional alternatives the impact of climate change amplifies existing unfavourable conditions (McCarthy et al., 2001) and resources are prone to exploitation because of the compromise that arises in the resource governing institutions. Global narratives on natural resource governance point to struggles of local governments with implementation of climate change adaptation policies (Agrawl et al., 2013, Nam et al., 2015). Various scholars have shown that management of environmental resources largely neglects complexity and the human dimension (Holling \& Meffe, 1996; Ludwig, 2001; Gleick, 2003; Pahl-Wostl, 1995, 2007 a, b, c). Uncontrolled cultivation and unsustainable harvesting of resources with corresponding influences in fragile watershed areas are some of the main human activities escalating environmental degradation (Ministry of Water and Environment, 2013).

Despite the presence of elaborate governance infrastructure composed of local government, NGOs and local environmental committees, Awoja watershed in Kyoga Water Management Zone of Eastern Uganda with an area of $10.281 \mathrm{~km}^{2}$ is a key watershed degradation hotspot with a perceived degradation rate of $76 \%$ as compared to $63 \%$ from Lake Victoria crescent and $41 \%$ in the south western farmlands 
of Uganda (NEMA, 2008; Turyahabwe et al., 2013). With increasing frequency of floods and draughts increasing degradation in this Watershed threaten the sustainability of the social and ecological system in the region. Virtually no part of Awoja watershed has remained untouched by the community's compulsion to transform nature and livelihoods in order to survive changing climatic conditions. As noted by (Turyahabwe et al., 2013; Qingqing, 2015; Junguo et al., 2016) in Akello et al. (2016), population growth, increased conflict on resource use and limited alternatives are some of the factors fueling land use changes in the Lake Kyoga Basin of which Awoja is part. However, little is known about the constraints posed by local interest factors on sustainable management of this watershed. As local institutions strive to manage and control access to natural resources in Awoja; local political, economic and social interests appear to be getting in the way leading to uncontrolled access to natural resources within the watershed.

Within Awoja watershed in Eastern Uganda little is known on the magnitude, extent and level of land use cover change (de Leeuw, 2016; Mbogga, 2014; Mutengeka et al., 2013). While recent studies have underscored the importance of quality of participation and information dissemination in watershed restoration, (Akello et al., 2017) little is known about the local influences and the human factors escalating the degradation of this watershed. This study sought to relate land use change to the governance of resource us in the watershed.

Owing to the fact that land use changes are not a consequence of climate change effects alone, characterizing the changes was important in order to unravel the causes of degradation as it went much beyond technologies and emphasized amalgamating technological tools with broad-ranging political, social and economic factors.

\section{Materials and Methods}

\subsection{Research Design}

The study applied a cross sectional survey research design. According to Amin (2005), a cross sectional survey is such study that is carried out at one point in time. The design employed both the qualitative and quantitative approaches to allow triangulation in data collection and data analysis that helped the researcher to obtain quality results. The approach of triangulation in a cross sectional research design was also supported by Amin (2005), as viable in generating quality results.

\subsection{The Study Area}

This study was conducted in Amuria, Katakwi and Soroti districts, in Awoja watershed of Eastern Uganda where draughts and floods have become frequent in the last decades. The watershed has experienced a high degradation rate of about $20 \%$ in the last two decades of about $20 \%$, which is much higher than the national average of $11 \%$ (MWE 2013).

Soroti district was purposively selected because it is host to the Awoja Wetlands where the greater part of the Awoja Watershed lies. Administratively Soroti has been the mother district from where most of the districts in Teso have been curved. Therefore it is most endowed with historical information on the 
watershed. Katakwi was selected because of its trans boundary interactions with Karamoja sub region and their struggles for common pool resources such as water and pasture during floods and draughts. Amuria district was selected due to its vulnerability to floods. Amuria is also the only district in Teso sub region that comprehensively implemented wetlands policy including the government interventions of wetlands demarcation and legislation.

Gweri Sub County in Soroti was selected due to its experiences with controversies surrounding wetlands encroachment; rice production and JICA rice interventions in Awoja wetlands while Magoro Sub County in Katakwi was purposively selected because of flood vulnerability and its struggles with Uganda Wild Life Authority (UWA) on demarcation of game reserves. Wera Sub County and the two parishes of Morungatuny and Okile in Amuria were selected because of their participation in the wetlands demarcation program by Amuria District Local government.

The communities in the sample area are mainly agro-pastoralists, practicing the Teso Farming System characterized by both crop production and livestock rearing. These areas suffer from similar incidents of flooding, draughts and displacements but vary widely in their water and land resource endowments and utilization. They also differ in the extent of implementing of natural resource laws and regulations. The sub-region experiences bi-modal type of rainfall and crop production is by far rain-fed. The crop production cycle follows the pattern of rainfall on annual basis. The average rainfall is $1,200 \mathrm{~mm}$ per annum. The vegetation of the sub-region can best be described as grassland-savanna predominated by grassland and shrubs. The soils are mainly sandy loam with variation from sandy to loamy soils depending on the terrain.

\subsection{Data Collection and Analysis}

\section{a) Remote Sensing}

Thematic classification of multispectral images was adopted to assess land use systems and cover changes in Awoja watershed. Image classification was performed, where satellite images were converted into thematic data. The process involved compressing a mosaic of pixels that belong to a common and relatively homogeneous class into one theme. The intention of image classification was to ease the analysis of thematic characteristics of some environmental features like land use/land cover within the GIS-basedmodeling.

The administrative boundary of the study area was projected to Universal Transverse Mercator (UTM) projection in Zone 36 North and datum of World Geodetic System (WGS 1984), same to that of the imageries. The administrative layer was used for clipping the imagery scene to the study area extent.

The information generated was mainly based on analyses of land use changes as shown by results of GIS maps generated over 10 year intervals. The images were accessed from U.S. Geological Survey provided through web portal of Earth Explorer (https://earthexplorer.usgs.gov/). Pre-processing and classification of Land sat images were carried out by using Harris ENVI 5.3 software. Standard methods, which included the use of image elements like tone, texture, shape, location, association, pattern, etc., of digital image processing were adopted for thematic land use land cover mapping. 
Training Signatures were developed aided by google imagery at $5 \mathrm{~m}$ spatial resolution obtained from Portable basemap Server (https://geopbs.codeplex.com/) within the ArcGIS software. With the high-resolution image, training samples were collected, evaluated, edited to create the training data (signature file) for use in the land use land cover classification. Ground truth points collected using the GPS was extracted into shape file data format using DNRGPS application version 6.1.0.6.

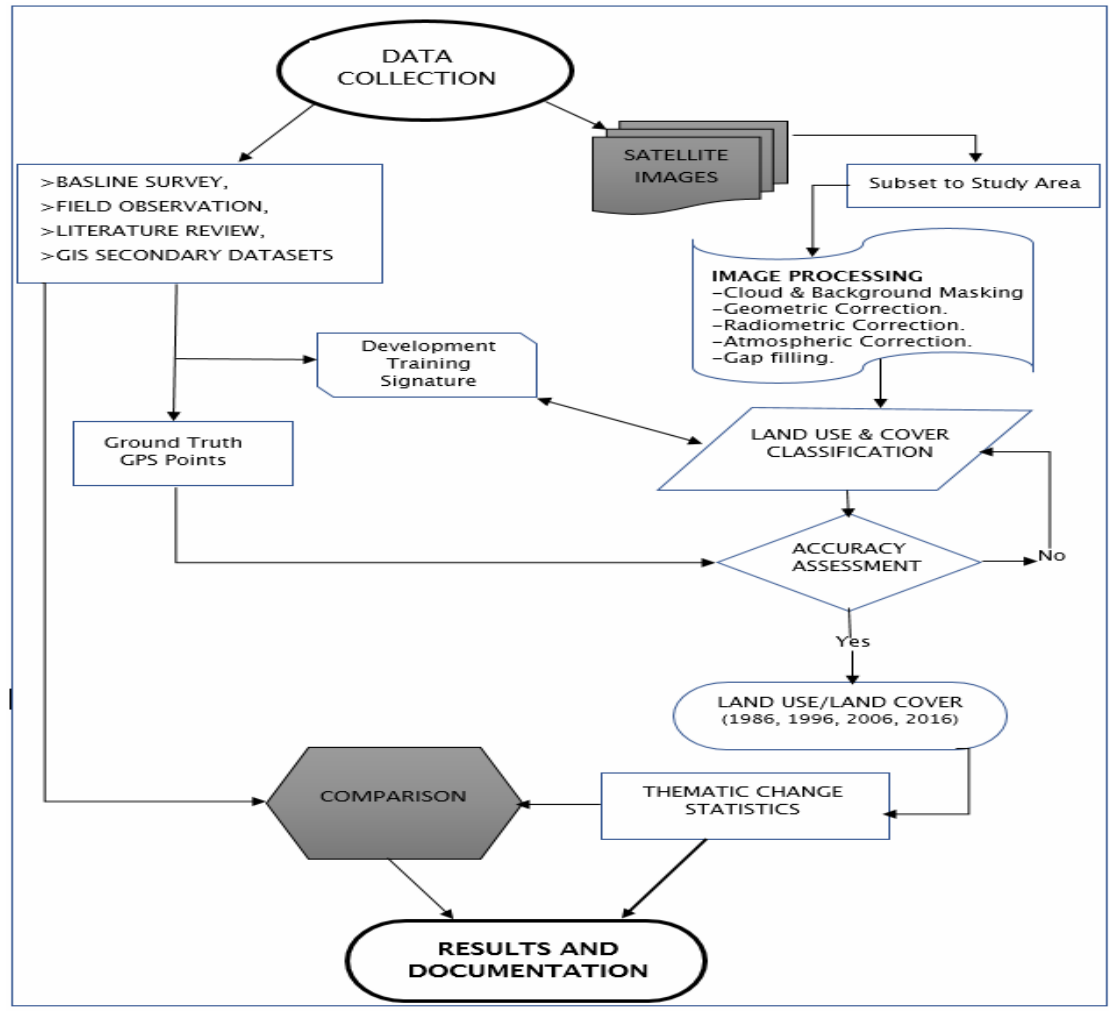

Figure 1. Remote Sensing Methodology

\section{b) Documents Review}

This involved a comprehensive literature review to capture information on legal, policy, administrative and implementation frameworks related to natural resource management at local government levels. It also reviewed relevant information and other studies from various sources. Some of the documents reviewed included: The National Climate Change Policy (NCCP, 2012), the Local Government Act (1997), The Decentralization Policy, Wetlands Protection Act, Development Plans, Annual Budgets, Monitoring and Evaluation Reports and many others.

\section{c) Key Informant Interviews}

This was used to collect primary data that was used to evaluate the policy development processes, including the principles in the framing of policies governing natural resource management. The tool was also used to measure variations between policy frameworks and real governance practices of 
natural resource management in a changing climate and influence of stakeholders on institutional practice.

Face-to-face/one-on-one interviews with civic leaders and leaders of NGOs involved in adaptation to climate change were carried out to achieve the above. Semi structured questionnaires were used due to their flexibility to probe for details. Inputs from people at various levels of governance, local government technical (Sub county: Senior Assistant Secretaries, Parish Chiefs, Environment Focal Point Officers, and political wing (LC III Chairperson, Councilors, and members of the Sub-county executive). Information was also collected from CSOs and extra local institutions (members of Parish Development Committees and members of Disaster Risk Management Committees)

\section{d) Focus Group Discussions}

This was organized at each sampled parish from all three sub counties under study. In all 6 FGDs were carried out. Each FGD had at least 8-12 people selected with the help of Local Government and NGO partners at the sub county. Efforts were made to cover variations among women, youth and the elderly. This was meant to measure community perceptions on local participation in resource management. It was also used to measure social inclusiveness of policies, and institutions governing adaptation in the study area. Secondly, FGDs were conducted at institutional levels to determine the organization profiles, institutional linkages, institutional interactions and changes in policy and practice among institutions involved in adaptation to climate change.

\section{Results}

The findings are presented starting with a description of the key land use systems in Awoja watershed, recent changes in land use patterns in the watershed, the key drivers of these changes and the implications for sustainability in this watershed are presented.

\subsection{Quantification of Key Land Use System in Awoja}

Figure 2 shows the subsequent land use cover maps for 1986, 1996, 2006 and 2016which had an overall map accuracy of $90.2 \%, 89.2 \%, 90 \%$ and $80 \%$ respectively for all the images by using the error matrix. 


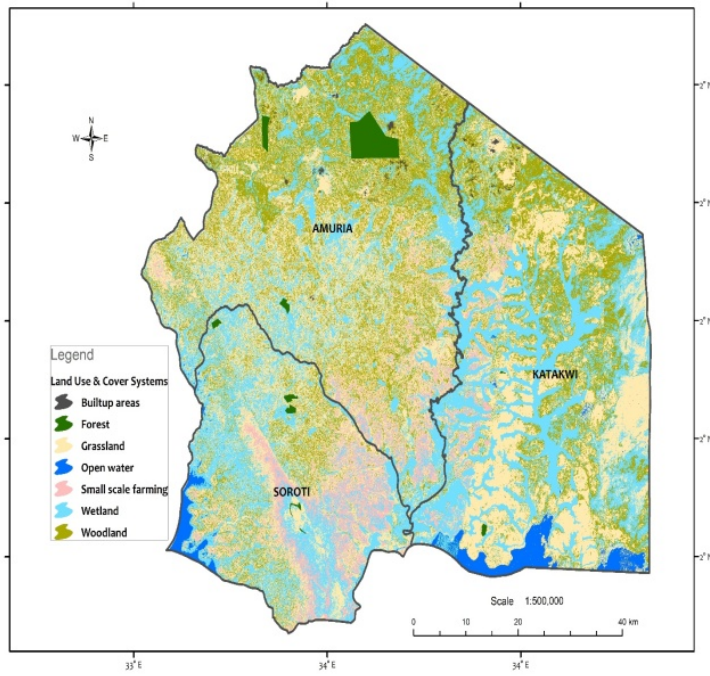

1986

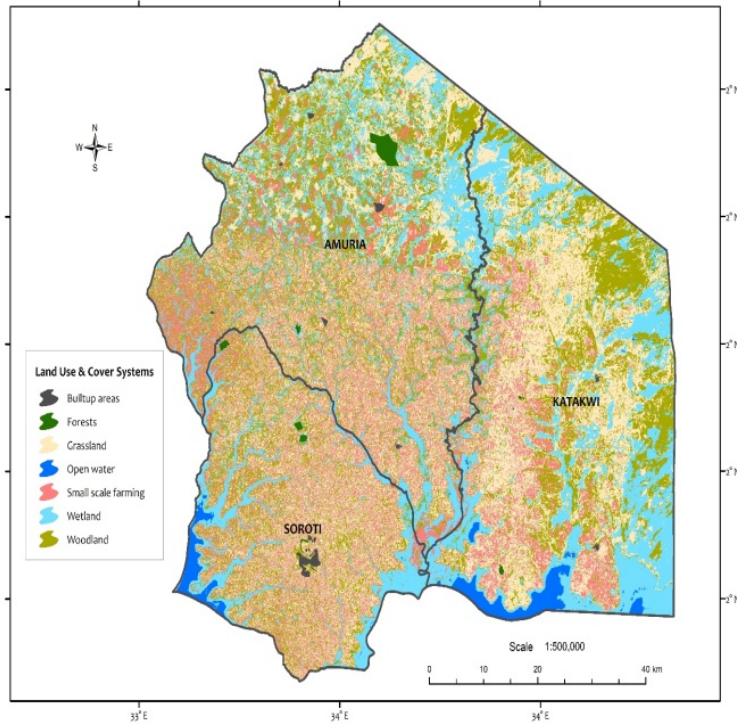

2006

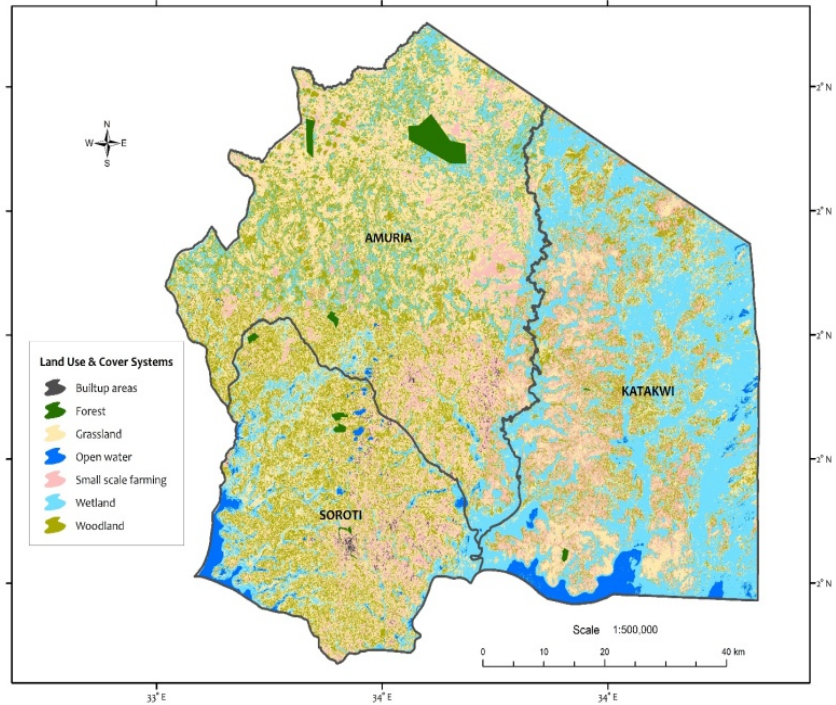

1996

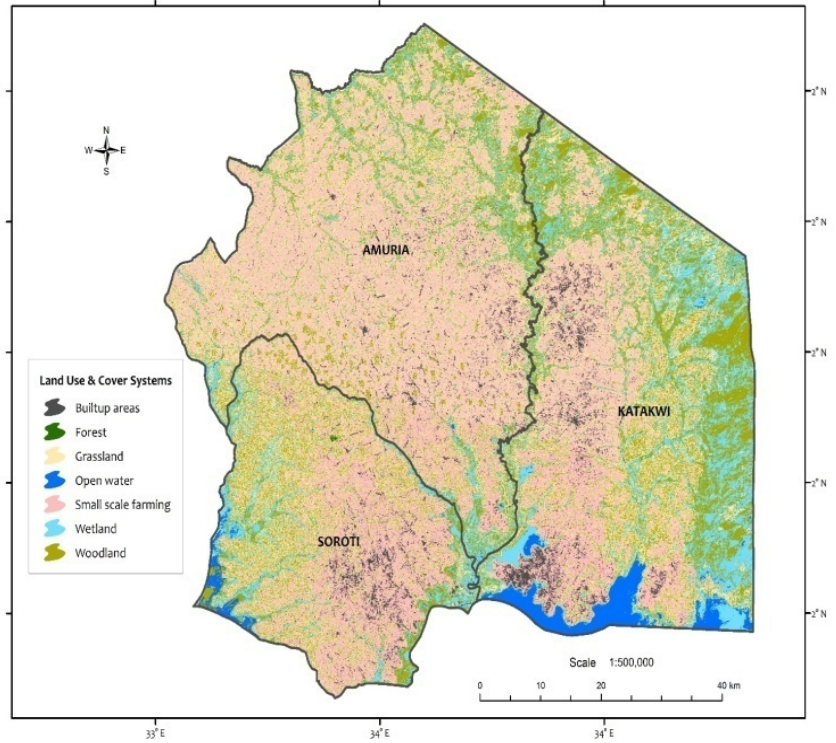

2016

Figure 2. Trends in Land Use Cover Changes from 1986-2016

This approach has been popular in evaluating per-pixel classification (Lu \& Weng, 2007) Kappa statistics were also computed for each classified map to measure the accuracy of the results for the three years giving $0.881,0.839,0.883$ and 0.791 for the above years respectively. The overall results are viable for subsequent analysis and change detection (Lea \& Curtis, 2010).

Table 1 shows the quantification of land use/cover over four decades from 1986-2016. The main land use types include grasslands covering $32.8 \%$ in 1986 but down to $27.81 \%$ in 2016 ; woodlands at 
$19.10 \%$ coverage in 1986 and $20.55 \%$ in 2016 . The built up areas covered is $18.9 \% \mathrm{Km}^{2}$ in 1986 representing $0.21 \%$ and $296.21 \mathrm{Km}^{2}$, representing $3.28 \%$ in 2016 . The area covered by wetlands was substantive at $2,810.87$ equivalent to $30.85 \%$ in 1986 but had reduced to $1,353.03 \mathrm{Km}^{2}$ equivalent to $14.85 \%$ by 2016 .

Table 1. Quantification of Land Use/Cover (1986-2016)

\begin{tabular}{|c|c|c|c|c|c|c|c|c|}
\hline & 1986 & & 1996 & & 2006 & & 2016 & \\
\hline Landcover Type & Area $\left(\mathbf{K m}^{2}\right)$ & $\%$ & $\begin{array}{l}\text { Area } \\
\left(\mathbf{K m}^{2}\right)\end{array}$ & $\%$ & $\begin{array}{l}\text { Area } \\
\left(\mathbf{K m}^{2}\right)\end{array}$ & $\%$ & $\begin{array}{l}\text { Area } \\
\left(\mathrm{Km}^{2}\right)\end{array}$ & $\%$ \\
\hline Built up areas & 18.9 & 0.21 & 43.71 & 0.48 & 146.64 & 1.59 & 298.61 & 3.28 \\
\hline Woodland & 1740.43 & 19.1 & 1863.64 & 20.46 & 2143.73 & 23.23 & 1872.36 & 20.55 \\
\hline Forest & 107.48 & 1.18 & 95.47 & 1.05 & 49.99 & 0.54 & 6.94 & 0.08 \\
\hline Grassland & 2988.42 & 32.8 & 3124.55 & 34.3 & 2579.18 & 27.94 & 2533.57 & 27.81 \\
\hline Open water & 814.58 & 8.94 & 729.14 & 8 & 635.92 & 6.89 & 669.25 & 7.35 \\
\hline Small scale farming & 629.44 & 6.91 & 865.09 & 9.5 & 1659.46 & 17.98 & 2376.64 & 26.09 \\
\hline Wetland & 2810.87 & 30.85 & 2388.67 & 26.22 & 2015.28 & 21.83 & 1353.03 & 14.85 \\
\hline
\end{tabular}

Figure 3 shows a graphical representation of the percentage coverage of land use types in Awoja watershed described above.

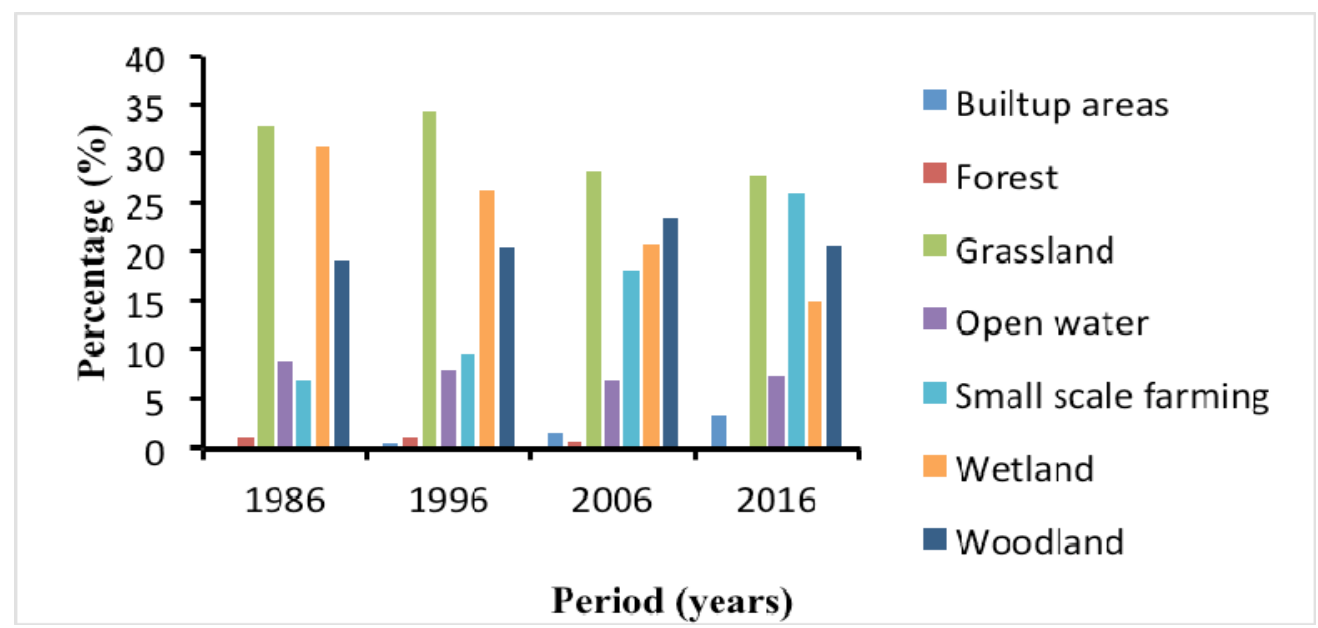

Figure 3. Graphical Representation of Land Use Cover in Awoja Watershed 1986-2016

\subsection{Land Use Cover Changes}

Table 4.2 shows the dynamic changes in land use/cover types from the period 1986 to 2016 . The table indicates an increase in built areas from 0.3\% between 1986-1996; to 1.7\% between 2006 and 2016. There is a notable decrease in forest cover from $107.48 \mathrm{Km}^{2}$ to $6.94 \mathrm{Km}^{2}$ by 2016 . The table also shows 
a dramatic increase in small scale farming area from $629.44 \mathrm{Km}^{2}$ to $2,376.64 \mathrm{Km}^{2}$ from $1986-2016$ while the area of wetland reduced from $2810.47 \mathrm{Km}^{2}$ to $1,355 \mathrm{Km}^{2}$ over the same period. It can also be seen from the table that the area covered by open water has reduced from $814.58 \mathrm{KM}^{2}$ to $669.25 \mathrm{Km}^{2}$ between 1986-2016.

The quantified changes in square kilometers and the percentage change in area is presented on table 2. The table indicates that the area covered by forests continued to decline from 1986-2016. It can also be seen from the table that despite positive changes in the land area between 1986-1996, the area covered by woodlands also declined over the last 2 decades; between 1996-2016.

Table 2. Land Use Systems and Cover Change Statistics

\begin{tabular}{|c|c|c|c|c|c|c|}
\hline $\begin{array}{l}\text { Land use Land } \\
\text { cover }\end{array}$ & $\begin{array}{l}1986 \text { to } 1996 \\
\text { Area (sq km) }\end{array}$ & $\%$ & $\begin{array}{l}1996 \text { to } 2006 \\
\text { Area (sq km) }\end{array}$ & $\%$ & $\begin{array}{l}2006 \text { to } 2016 \\
\text { Area }(\mathrm{sq} \mathrm{km})\end{array}$ & $\%$ \\
\hline Built-up areas & 24.8 & 0.3 & 102.9 & 1.1 & 152.0 & 1.7 \\
\hline Woodland & 123.2 & 1.4 & 280.1 & 3.1 & -271.4 & -3.0 \\
\hline Forest & -12.0 & -0.1 & -45.5 & -0.5 & -43.1 & -0.5 \\
\hline Grassland & 136.1 & 1.5 & -545.4 & -6.0 & -45.6 & -0.5 \\
\hline Open water & -85.4 & -0.9 & -93.2 & -1.0 & 33.3 & 0.4 \\
\hline $\begin{array}{ll}\text { Small } & \text { scale } \\
\text { farming } & \end{array}$ & 235.6 & 2.6 & 789.4 & 8.7 & 722.2 & 7.9 \\
\hline Wetland & -422.2 & -4.6 & -488.4 & -5.4 & -547.3 & -6.0 \\
\hline
\end{tabular}

Figure 4 shows a graphical representation of the percentage changes in land use in Awoja watershed over the period 1986-2016. As shown, there was continued reduction in the wetlands area all through 1986-1996, 1996-2006 and 2006-2016. The built up area of the watershed continued to increase all through the period 1986-2016. The area covered by grassland that had increased between 1986-1996, declined from 1996-2016, while the area covered by forests continued to decline all through the period from 1986-2016. 


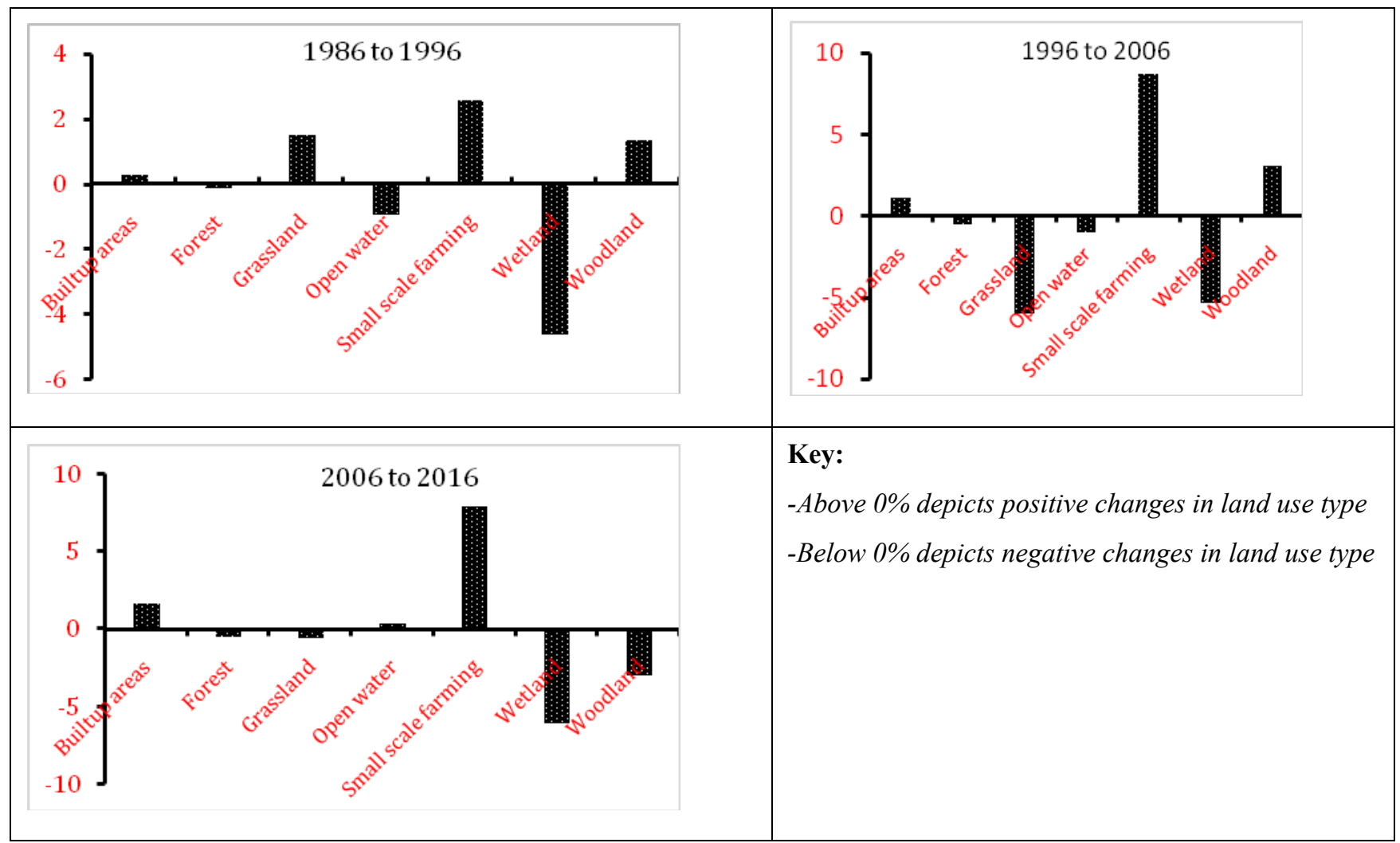

Figure 4. Changes in Land Use in Awoja Watershed

\subsection{Drivers for Land Use Changes in Awoja Watershed}

Land use changes in the watershed were a result of inadequate control of access to resources, which can be linked to the local political, social and economic factors. Results from the household survey showed some of the major factors responsible for the escalation of land use changes. Close to equal proportions of respondents $(32.8 \%$ and $30 \%)$ felt that there is overgrazing in the wetlands and that wetlands have been highly encroached. $29 \%$ felt that there was over cultivation and increased access to wetland resources, while $8 \%$ felt that the forests have been cleared.

Table 3. Perception of Respondents on Changes in Land Use and Control $(n=180)$

\begin{tabular}{lcl}
\hline How demand for land has affected protection of wetlands & (\%) & Cum. \\
\hline Forests have been cleared & 7.78 & 7.78 \\
Over cultivation and increased access to wetlands & 29.44 & 37.22 \\
There is over grazing in wetlands & 32.78 & 70.00 \\
Wetlands have been highly encroached & 30.00 & 100.00 \\
\hline Total & 100.00 & \\
\hline
\end{tabular}

From the KII Technical staff from environment department indicated that there was reluctance for the local government administrative and political staff to control access to wetlands resources and that Published by SCHOLINK INC. 
some of the leaders were also involved in wetlands cultivation. Politicians were also reported to be lenient to the population in order protect their votes.

Participants in Focus Group Discussions identified a number of factors that were considered drivers of land use changes observed within the watershed as presented on Table 4.4. Secondary data from fieldwork of the Climate Change and Rural Institutions CCRI project was also used to corroborate the data obtained.

The participants mentioned six major drivers of land use change in Awoja watershed, which were categorized into four main types namely: Climatic, Demographic, Policy and socio economic factors. Climatic factors include increased frequency of floods and draughts that were perceived to have been responsible for changes in vegetation cover, water levels and infrastructure. From the household survey all the respondents ever experienced floods or draughts. However, $46 \%$ and $44 \%$ of the respondents were adversely affected by the problems of floods and draughts respectively. Demographic factors comprised of increase in population and population distribution and migration were perceived to have been responsible for increase in built areas, reduced land for cultivation and increasing resource use conflicts. $30 \%$ and $41 \%$ of the respondents reported the problem of loss of land and land conflicts respectively.

Table 4. Perceived Drivers of Land Use Changes in Awoja

\begin{tabular}{ll}
\hline Observed changes & Driver \\
\hline Reduced vegetation cover & Increasing frequency of droughts \\
$\begin{array}{l}\text { Increased wetlands cultivation } \\
\text { Reduced water availability }\end{array}$ & \\
Increase in water coverage & Increasing frequency of floods \\
Displacements of communities and emergence of camps & \\
Reduction in land for cultivation & \\
$\begin{array}{l}\text { Destruction of infrastructure: Roads, schools, health } \\
\text { centres }\end{array}$ & \\
Increased in built areas & \\
Increased small scale farming & \\
Land fragmentation & \\
Reduced forests, woodlands and vegetation cover & \\
Reduced communal land area & \\
Increased cultivation in uplands, displacements from & Government Interventions (land demarcation for \\
wildlife areas to wetlands in Magoro, restrictions in & conservation) \\
cutting of endangered tree species, promotion of some & \\
enterprises e.g upland rice. & \\
\hline
\end{tabular}


Increase in built areas, increasing demand for fuel wood, Migration of agro pastoralists communities decreasing water resources

Increased cultivation in wetlands, emergence of new Socio economic pressures enterprises such as piggery, and charcoal burning.

Government interventions mainly in the form of demarcation of wetlands and conservation areas were perceived to have been responsible for displacement and evictions from traditional cultivation areas. Farmers mentioned that demarcation had marginalized cultivators and benefited livestock farmers who were being allowed to graze their animals in the wetlands after the demarcation. From the FGD, a local leader of Omugenya in Gweri sub-county in Soroti District pointed out that "overgrazing by cattle keepers some of who come from outside the district had led to degradation of the Gweri wetlands" below is a detailed presentation on mobility as a cause of land use changes in the watershed.

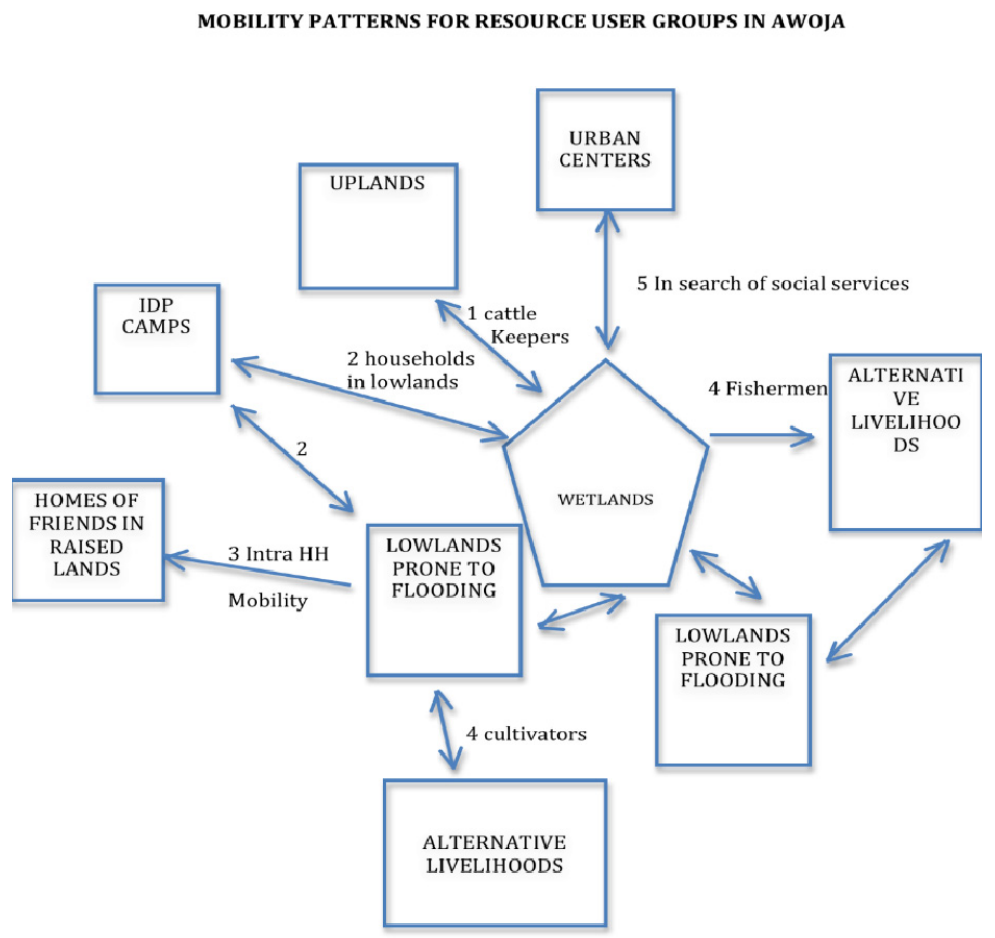

KEY:

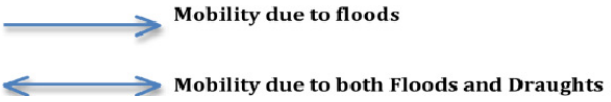

Figure 5. Mobility as a Driver to Land Use Changes

Figure 5 indicates the mobility patterns within Awoja watershed in a changing climate. During heavy rains, because of floods, the cattle keepers move from lowlands to uplands and when there is drought 
they return to the lowlands. This has significant effects on other enterprises in the uplands wherethere is intense competition with cattle keepers for grazing land. It was also noted that during floods, some community members who reside in low lands move to Internally Displaced Peoples Camps or even to homes of relatives in uplands. This creates a number of social and economic challenges that lead to compromises in enforcing rules governing resources use. It was revealed during interviews that whenever people moved from one place to another because of climate change, some never went back because they take up new income generating alternatives and others move to urban centers where they hide and do not want to come back to the villages. It was further revealed that the climate mobility was happening in all districts within the Awoja region and the impact on resources use had been the resulting land use changes that are a further challenge in Awoja watershed.

Finally, socio economic pressures including food security needs, family incomes and social needs were deemed to have created competition for resources leading to increased cultivation of wetlands and monetization of rice and charcoal burning, sand mining and other natural resources. From the household survey, $46 \%$ and $39 \%$ of the respondents were involved in commercial charcoal burning and selling of fuel wood respectively. Further, $48 \%, 21 \%$ and $14 \%$ were encroaching on the wetlands for purposes of fishing and rice growing, cutting grass for thatching and grazing of animals respectively. $85 \%$ of the respondents were involved in sand mining.

\subsection{Implications of Land Use Changes for Sustainability}

Respondents' views on the implications of land use changes for the sustainability of the ecological and social system in Awoja watershed is shown in Table 5.

Table 5. Respondents Views on the Implications of Land Use Change for Sustainability

\begin{tabular}{|c|c|c|}
\hline Land Use change & $\% \quad$ of & Implications for sustainability \\
\hline & Respondents & \\
\hline $\begin{array}{l}\text { Increased cultivation of } \\
\text { communal land }\end{array}$ & 14.0 & $\begin{array}{l}\text { Access denied for other users, resource governance rules } \\
\text { compromised. }\end{array}$ \\
\hline $\begin{array}{l}\text { Increased fishing involving both } \\
\text { men and women }\end{array}$ & 47.9 & Survival of some fish species threatened \\
\hline $\begin{array}{l}\text { Increasing rice cultivation in the } \\
\text { wetlands }\end{array}$ & 47.9 & Wetlands degradation (siltation, over flooding) \\
\hline Sand Mining in the Watershed & 85.0 & $\begin{array}{l}\text { Water logging, harbors diseases agents such as } \\
\text { mosquitoes, destroys landscapes }\end{array}$ \\
\hline $\begin{array}{l}\text { Increasing sale of fuel wood and } \\
\text { Charcoal by both men and } \\
\text { women }\end{array}$ & 84.7 & Deforestation and alteration of the water cycle. \\
\hline Increasing livestock numbers & 13.6 & Overgrazing in the wetlands, destruction of bird roosting \\
\hline
\end{tabular}


The respondents mentioned threats to the ecological system posed by increasing cultivation in the wetlands as well as cattle grazing in both the wetlands and uplands in the swamp fringes. Cattle grazing and upland farming activities are perceived to have resulted in increased soil erosion into the wetlands. Increased sedimentation to the wetlands has affected the water levels as well as fish habitats in the downstream.

Increasing use of illegal fishing methods, increased sale of fuel wood and charcoal, sand mining and increasing encroachments on the Ramsar Sites all pose threats to the ecological system as forest and fish resources get depleted and breeding sites of important bird species in the Ramsar sites are destroyed. Respondents also mentioned that increased grabbing of communal land by individuals and families nearest to them denied access for some community members. It was mentioned that some individuals annex, cultivate and or fence off communal grazing areas and cattle tracks and routes to water sources.

Keeping large numbers of cattle and goats was also mentioned as a risk to crops especially cassava. It was mentioned that during dry conditions when pasture is inadequate, most livestock especially goats are left to wonder on free range and end up destroying crops in the field. Consequently, the communities have adopted the practice of sending all animals to the wetlands in a sort of free-range -community-ranching system.

\section{Discussion of Results}

The research findings show how the land use systems in Awoja watershed have been changing over the last 3 decades 1986-2016.These spatial and temporal changes are discussed in the context of political ecology of watershed management in a changing climate. The notable changes in the last decade has been the reduction in the wetlands, an increase in built area, an increase in small scale agriculture, a reduction in the forest cover, a reduction in the wood land and an increase in built up area. Whereas the open water area had decreased between 1986 and 1996 as well as from 1996-2006, there was an increase in open water area between 2006 and 2016 the trend shows an increasing recovery of open water area. This trend depicts an increase in human activity on the two major lakes Bisina and Opeta and the rivers that feed them.

All these changes have occurred despite the presence of environment and climate change management institutions and signify the need to in contribution of the human agency in watershed degradation as well as the struggles of local institutions with the management of natural resources in a changing climate.

The findings also show an increase in small scale farming comprising by small plots of between 0.5 to 
1 acre, which characterize land fragmentation. Increase in small scale agricultural area has been at the expense of forests, woodlands and wetlands. The influence of population pressure on land use for agriculture is consistent with the views of Keter (2011), who argued that the social economic activities of an area are highly influenced by the type of population in that area. Gebreyesus and Kirubel (2009) reported that the heavy reliance of some 85 percent of Ethiopia's growing population on an exploitative kind of subsistence agriculture is a major reason behind the current state of land degradation. In Awoja a higher population growth rate is pushing people to use all the land available including those within the proximity of the rivers, the lakes and the wetlands, which is not a good signal. The findings are in line with Kaggwa et al. (2009) who found that agriculture was the principal cause of watershed degradation. Land fragmentation has arisen from increasing population and traditional practice of dividing land among the children.

While increasing birth rates and climate induced migration appears to have an influence on land use in Awoja watershed, control of access to environmental resources will play a big role in environmental protection. This suggests that while any land use improvement policy must focus on tackling both the birth rate challenge and the climate change effects in order to strike a land use equilibrium that is sustainable, policy implementation should emphasize compliance and plan to curb political processes that weaken control of access to the resources.

\section{Conclusions and Recommendations}

The major characteristics of land use changes in Awoja depict the effects of climate change and human activity and the weakness of institutions in controlling access and use of natural resources as shown by decrease of forest cover, decrease in wetland areas and increase of built up areas. The key conclusion in this study is that there is an increasing trend of land degradation in Awoja watershed as seen from the period 1986-2016, which needs to be curbed. While the land use changes are perceived to be due to population and climate change pressures, there is need to focus on the control of access to environmental resources in this watershed. Therefore, a good analysis of the local institutional factors catalyzing the degradation of the watershed in required in order to design appropriate management program for the watershed. The results also indicated the forest

cover has reduced because of human activity and this has contributed greatly to changes in weather conditions including long drought periods and heavy rains leading to flooding in the Watershed. The role of institutions has been characterized with compromises which limit the capacity to enforce the rules governing resources use in the watershed. Generally, the study concludes that degradation in the watershed is vivid and is as much a result of increased human activity brought about by climate change. In view of the findings it is recommended that diversification of income sources that draws away communities from over reliance on the Awoja watershed resources is essential. This would include adoption of low risk but high yielding enterprises such as fruit production and tree planting in the uplands. The other recommendation is that local governments need to sensitize the community on the 
gravity of the current trends of degradation and enact bylaws to control the human causes of degradation of Awoja watershed particularly the current uncontrolled access to wetlands for rice cultivation and over fishing as well as deforestation.

\section{References}

Akello, S., Turyahabwe, N., Okullo, P., \& Agea, J. G. (2016). Changes in Land use/cover change and perceived status of Awoja in eastern Uganda. African Journal of Environmental Science and Technology, 10(11), 406-414. https://doi.org/10.5897/AJEST2016.2136

Amin, M. E. (2005). Social Science Research: Conception Methodology and Analysis. Kampala: Makerere University Printeryafd.

de Leeuw, J. (2016). Trees and Watershed Management in Karamoja, Uganda. Evidence on Demand. Climate \& Environment, Infrastructure and Livelihoods. A quick desk study commissioned by DFID Uganda.

Gebreyesus, B., \& Kirubel, M. (2009). Estimating Soil Loss Using Universal Soil Loss Equation (USLE) for Soil Conservation planning at Medego Watershed, Northern Ethiopia. Journal of American Science, 5(1), 5869

Ibrahim, R. H., \& Mosben, R. K. (2015). Monitoring urban growth and land use change detection with GIS and remote sensing techniques in Dagahlia governorate Egypt.

IPCC. (2007a). Climate Change 2007: The Physical Science Basis. Contribution of Working Group I to the Fourth Assessment Report of the Intergovernmental Panel on Climate Change.

Krumhansl, K., Jamieson, R., \& Krkosek, W. (2016). Using species traits to assess human impacts near shore benithic ecosystem in the Canadian Artic. Canada. Ecol. Indic., 60, 495-502. https://doi.org/10.1016/j.ecolind.2015.07.026

Leach, M., \& Mearns, R. (1996). The lie of the land: challenging received wisdom on the African environment. Oxford: James Currey; Portsmouth, NH: Heinemann.

Mbogga, M., Malesu, M., \& De, Leeuw, J. (2014). Trees and watershed management in Karamoja, Uganda (Vol 4, p. 25). Evidence on Demand, UK. https://doi.org/10.12774/eod_hd.december2014.mboggametal

Ministry of Water and Environment. (2013). The National Forest Plan 2011/12-2021/22.Directorate of Environment affairs, Kampala.

Mugende, O. M., \& Mugenda, A. G. M (1999). Research Methods. Nairobi: African Center fortechnology Studies Press.

Palmer, M. A. (2009). Reforming Watershed Restoration: Science in Need of Application and Applications in Need of Science. Estuaries Coasts, 32, 1-17. https://doi.org/10.1007/s12237-008-9129-5

The Constitution of the Republic of Uganda. (1995). The Ministry of Justice and Constitutional Affairs, Kampala-Uganda 
Townsend, P. V., Harper, R. J., Brennan, P. D., Dean, C., Wu, S., Smettem, K. R. J., \& Cook, S. E. (2011). Multiple environmental services as an opportunity for watershed restoration. For Policy Econ., 17, 45-58. https://doi.org/10.1016/j.forpol.2011.06.008 